Prosiding Seminar Nasional Pendidik dan Pengembang Pendidikan Indonesia dengan Tema "Membangun Generasi Berkarakter Melalui Pembelajaran Inovatif”. Aula Handayani IKIP Mataram 14 Oktober 2017. ISSN 2598-1978

\title{
REPRESENTASI MENTAL DAN PROSES KOGNITIF YANG MENDASARI TECHNOLOGICAL PEDAGOGICAL AND CONTENT KNOWLEDGE (TPACK)
}

\author{
Tomi Listiawan \\ STKIP PGRI Tulungagung \\ tomi@stkippgritulungagung.ac.id
}

\begin{abstract}
Abstrak: TPACK adalah sebuah kerangka kerja (framework) yang menggambarkan pengetahuan yang diperlukan guru untuk mengintegrasikan teknologi dalam merancang, melaksanakan, serta mengevaluasi pembelajaran. TPACK menggabungkan strategi berpikir kapan, dimana, dan bagaimana menggunakan suatu ranah pengetahuan (technology, pedagogy, dan content) dengan berbagai strategi pembelajaran dengan menggunakan teknologi yang tepat. Oleh beberapa penulis, TPACK dipahami sebagai potongan-potongan pengetahuan yang tidak koheren satu sama lain, di lain pihak, terdapat ahli yang memahami TPACK sebagai teori-teori yang koheren. Makalah ini mendeskripsikan kajian literatur tentang dua hal tersebut, kemudian menyajikan peluang studi dan penelitian terkait proses kognisi yang mendasari TPACK.
\end{abstract}

Kata Kunci: TPACK, model mental, representasi mental

\section{PENDAHULUAN}

Dewasa ini perkembangan bidang TIK khususnya teknologi komputer dan internet telah jauh mempengaruhi segala bidang kehidupan manusia. Saat ini telah terjadi eksplosi (ledakan) kemajuan TIK (Banas, 2010; Listiawan, 2015). Hampir segala jenis pekerjaan manusia dapat lebih mudah dan lebih cepat diselesaikan berkat perkembangan dan kemajuan di bidang TIK.

Bagi guru, penguasaan pengetahuan tentang teknologi dalam pendidikan menjadikan guru mampu beradaptasi dengan perkembangan zaman yang ada. Sebagai guru yang profesional, sudah selayaknya guru selalu bisa mengembangkan kompetensi dirinya terutama dalam bidang pembelajaran. Salah satu cara pengembangan kompetensi ini adalah dengan penguasaan dan pemanfaatan teknologi. Jika pada masa lalu ada anggapa bahwa pembelajaran tidak terlalu perlu menggunakan media berbasis TIK, pada era saat ini penggunaan media berbasis TIK merupakan suatu keharusan.

Penguasaan Teknologi Informasi dan Komunikasi kini menjadi bagian dari tuntutan kompetensi guru, baik guna mendukung pelaksanaan tugasnya (penyusunan perencanaan, penyajian pembelajaran, evaluasi dan analisis hasil evaluasi) maupun sebagai sarana untuk mencari dan mengunduh sumber-sumber belajar. Sehingga setiap guru pada semua jenjang harus siap untuk terus belajar TIK guna pemenuhan tuntutan kompetensi tersebut. Pada Peraturan Pemerintah (PP) Nomor 74 Tahun 2008 tentang Guru, menyatakan bahwa "Kompetensi guru meliputi kompetensi pedagogik, kompetensi kepribadian, kompetensi sosial, dan kompetensi profesional yang diperoleh melalui pendidikan profesi".

Saat ini penggunaan perlengkapan maupun peralatan TIK telah menjadi sesuatu yang lazim dilingkungan pendidikan, siswa tumbuh dan berkembang dengan produk dari TIK, namun bagaimana mengintegrasikan TIK dalam pengajaran di kelas terus menjadi tantangan selama bertahun tahun (Shafer, 2008; So \& Kim, 2009). Guru merasa tidak cukup siap dan tidak memiliki kerangka teori yang kuat untuk digunakan sebagai subjek khusus penerapan TIK dalam pembelajaran (Brush \& Saye, 2009). Untuk mengatasi tantangan tersebut, baru-baru ini telah muncul kerangka teoritis penting untuk memandu penelitian yang dapat digunakan guru terkait dengan integrasi TIK dalam pembelajaran yaitu Technological Pedagogical and Content Knowledge (TPACK).

\section{PENGETAHUAN GURU : TINJAUAN HISTORIS}

Guru menjadi tulang punggung bagi keberhasilan proses pembelajaran. Berbicara tentang pengetahuan apa yang diperlukan guru dalam melakukan pembelajaran, telah menjadi perhatian para ilmuwan sejak beberapa abad yang lalu, dengan perubahan yang signifikan pada awal abad ke 20 (Parkay\&Stanford,2008). Pada akhir abad ke 19, tercatat bahwa guru membutuhkan pengetahuan konten dalam mengajar. Pandangan ini kemudian bergeser pada pentingnya pemahaman guru tentang bagaimana mengajar, bagaimana guru mempersiapkan penerapan praktek belajar mengajar (pedagogi) sesuai dengan suatu konten dalam rencana pembelajaran. Pergeseran signifikan terhadap permasalahan ini terjadi pada akhir tahun 1980-an. Shulman (dalam F. W.Parkay \& B. H. Stanford, 2008) merumuskan kembali pengetahuan minimal yang harus dikuasai oleh seorang meliputi:

- Content knowledge / Pengetahuan konten

- General pedagogical knowledge / Pengetahuan pedagogi

- Curriculum knowledge / Pengetahuan kurikulum

- Pedagogical content knowledge / Pengetahuan konten pedagogi 
Prosiding Seminar Nasional Pendidik dan Pengembang Pendidikan Indonesia dengan Tema "Membangun Generasi Berkarakter Melalui Pembelajaran Inovatif”. Aula Handayani IKIP Mataram 14 Oktober 2017. ISSN 2598-1978

- Knowledge of learners / Pengetahuan tentang peserta didik

- Knowledge of educational contexts / Pengetahuan tentang konteks pendidikan

- Knowledge of educational ends, purposes, and values / Pengetahuan tentang tujuan, makna, dan nilai-nilai pendidikan

Pada tahun 1987, muncul pendapat bahwa diantara semua pengetahuan tersebut pengetahuan konten pedagogi (Pedagogical Content Knowledge / PCK) telah merepresentasikan pemahaman seorang guru tentang bagaimana topik-topik, permasalahan, atau persoalan tertentu diatur, direpresentaikan, serta disesuaikan dengan minat dan kemampuan peserta didik dan dituangkan dalam pembelajaran (Shulman,1987). PCK menjadi perhatian banyak pihak selama bertahun-bertahun.

Identifikasi pengetahuan khusus bagi guru ditahun 1987 (Wilson, Shulman, \& Richert,1987) tersebut sangat jauh berbeda dengan pendapat sebelumnya. Hal ini memicu pelaksanaan berbagai penelitian yang lebih ekstensif dan diskusi-diskusi keilmuan tentang sifat PCK dan program-program yang cukup mumpuni untuk mempersiapkan guru dalam mengembangkan PCK-nya. Perubahan ini mendorong banyak program pendidikan guru matematika dan sains untuk mendesain ulang program penyiapan guru yang secara eskplisit mengembangkan pengetahuan konten pedagogi (PCK) guru secara lebih komprehensif. Gambar 1 menunjukkan deskripsi visual yang digunakan untuk mendesain ulang program tersebut. Visualisasi ini menguatkan pentingnya beberapa domain pengetahuan guru yang meliputi pengetahuan guru tentang peserta didik, pedagogi, kurikulum, materi pelajaran, dan sekolah sebagai satu kesatuan yang kompleks dan saling berhubungan dengan PCK dalam alur yang menghubungkan semua domain pengetahuan. Hasilnya, program penyiapan guru berfokus pada integrasi domain-domain pengetahuan yang dipandang sebagai bagian tak terpisahkan dalam belajar dan pembelajaran matematika dan sains (Niess, 2001). Program penyiapan guru lebih menekankan pada pembentukan tentang pengetahuan pedagogi khusus daripada pedagogi umum. Penekanan tersebut dimaksudkan supaya calon guru dapat memikirkan dan merefleksikan beberapa domain pengetahuan pada saat membahas setiap pokok bahasan ataupun tugas. Semua hal tersebut bertujuan membimbing calon guru dalam mengembangkan sebuah pengetahuan yang menggabungkan PCK yang terintegrasi dan saling berhubungan untuk kepentingan pengajaran.

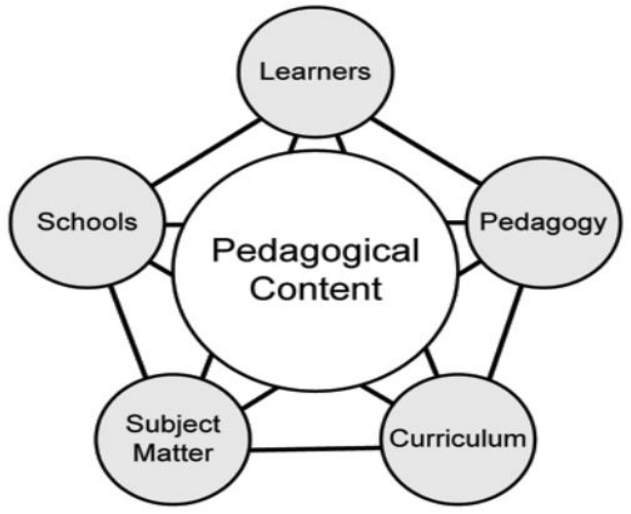

Gambar 1. Penampakan visual hubungan dan interaksi enam domain pengetahuan guru

Ditengah perkembangan pandangan tentang pengetahuan yang diperlukan oleh guru dalam mengajar, sebuah ledakan pengetahuan teknologi secara signifikan telah meningkatkan kemampuan manusia dalam "mengubah dunia" melalui penemuan teknologi berbasis komputer (American Association for the Advancement of Science, 1989). Seiring dengan kemajuan teknologi yang menyulut terjadinya era industri di abad ke-20 (Hillstrom, dalam F. W.Parkay \& B. H. Stanford, 2008), penemuan komputer dan internet menjembatani perjalanan masyarakat ke era informasi dan komunikasi di abad ke-21 (Parkay \& Stanford, 2008). Perkembangan teknologi komputer menjadikan kemudahan akses untuk tujuan kemajuan pendidikan. Beberapa pendidik telah memvisualiasikan penggunaan teknologi komputer sebagai alat pembelajaran meskipun sebagian besar teknologi digital baru muncul di era 1980-an. Perluasan internet dan menjamurnya jutaan interkoneksi jaringan komputer mulai memberi dampak dalam kehidupan sehari-hari pada awal tahun 1990-an. Dampak tersebut berlanjut menjadi ketergantungan yang semakin besar terhadap teknologi informasi dan komunikasi. Pergeseran dinamis ini dengan cepat menantang munculnya ide mendasar tentang pengetahuan dan keterampilan apa yang dibutuhkan untuk menjadi seseorang yang produktif (Niess, Lee \& Kajder, 2008).

\section{PENGETAHUAN GURU DI ERA TEKNOLOGI}

Dewasa ini guru dihadapkan pada tantangan dan pertanyaan kapan dan bagaimana mengintegrasikan teknologi digital baru dengan yang telah berkembang untuk mengajar dan belajar berbagai topik materi 
pelajaran matematika. Dengan beberapa pengecualian, pendidikan sebelum dan di perguruan tinggi guru-guru tersebut tidak mempersiapkan mereka dengan teknologi ini.

Pengalaman guru dan siswa tentang teknologi digital berbeda secara signifikan. Oleh karena itu banyak pihak harus terlibat dalam penelitian pengalaman guru, calon guru, dan pengembangan profesional untuk merekonstruksi cara pikir guru terhadap pengintegrasian teknologi baru dengan teknologi yang telah berkembang sebagai alat belajar mengajar. Pengalaman apa yang dibutuhkan guru agar mampu mereformasi pendidikan dengan menerapkan teknologi sebagai alat dalam kegiatan belajar mengajar di kelas? Apakah pengetahuan terhadap materi pelajaran dapat secara otomatis beralih menjadi pengetahuan terhadap penggabungan teknologi yang tepat sebagai alat belajar dalam topik-topik tertentu? Bagaimana guru perlu dipersiapkan untuk mengajarkan konten dalam cara-cara yang belum pernah mereka pelajari sebelumnya? Saat ini program pendidikan guru dihadapkan pada permasalahan kompleks dengan tuntutan yang dinamis sehingga mereka harus menerima dan menyambut dunia pendidikan guru diabad ke-21 (Koehler \& Mishra, 2008).

Pengetahuan untuk memadukan teknologi baru dengan teknologi yang sedang berkembang yang diperlukan guru dalam pengajaran telah banyak dikaji. Banyak peneliti yang mengusulkan pengintegrasian antara teknologi, pedagogi, dan konten dengan cara yang sama seperti yang telah dilakukan Shulman dalam mengusulkan PCK. Technological Pedagogical Content Knowledge (TPCK) diusulkan sebagai interkoneksi dan interseksi dari pengetahuan teknologi, pedagogi, dan konten (Mishra \& Koehler, 2006; Niess, 2005). Seiring waktu, kesulitan penamaan TPCK membawa akronim TPCK dalam sebutan baru yaitu TPACK (baca: tee-pack). TPACK diusulkan sebagai kerangka kerja dinamis untuk menggambarkan pengetahuan yang dapat diandalkan oleh guru dalam merancang dan mengimplementasikan kurukulum dan pembelajaran disamping membimbing siswa untuk berpikir dan belajar dengan menggunakan teknologi dalam berbagai persoalan.

Koehler dan Mishra (2008) menjelaskan permasalahan yang dihadapi oleh banyak guru dalam mengintegrasikan teknologi dalam pembelajaran sebagai sebuah "masalah kompleks dan masalah tidak terstruktur yang melibatkan interaksi dari berbagai faktor". Mereka menjelaskan TPACK sebagai suatu kerangka pengetahuan yang cukup fleksibel yang perlu dikembangkan oleh guru agar dapat mengintegrasikan teknologi dalam pembelajaran. Mereka juga menjelaskan beberapa bagian dari perpotongan antara pengetahuan teknologi, pedagogi, dan konten yang meliputi: pengetahuan konten / Content Knowledge (CK), pengetahuan pedagogis/Pedagogical Knowledge (PK), pengetahuan teknologi/Technological Knowledge (TK), pengetahuan konten pedagogis / Pedagogical Content Knowledge (PCK), pengetahuan konten teknologi I Technological Content Knowledge (TCK), pengetahuan pedagogis teknologi / Technological Pedagogical Knowledge (TPK), dan yang terakhir Technological Pedagogical Content Knowledge (TPACK) seperti tampak pada gambar 2 .

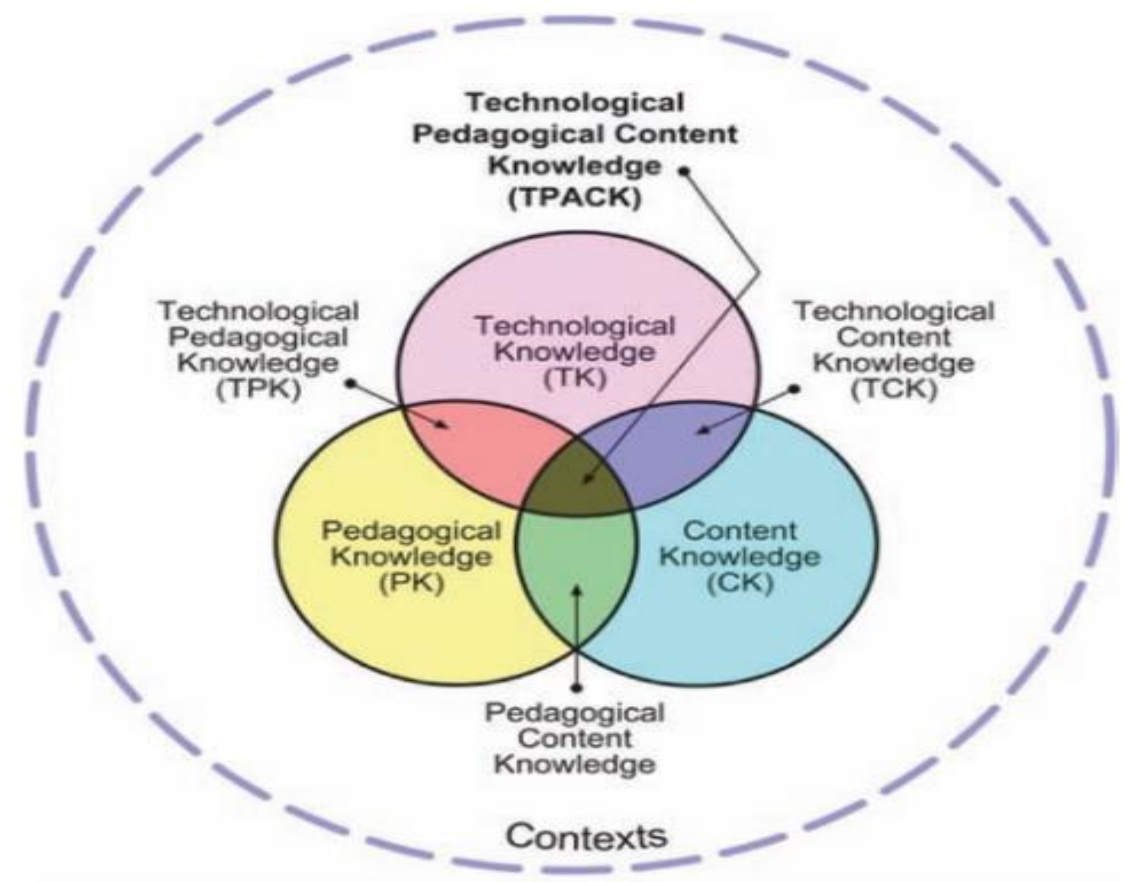

Gambar 2. TPACK: menggambarkan domain pengetahuan dan irisannya TINJAUAN KOGNITIF PADA TPACK

Kerangka kerja dan komponen-komponen TPACK menyajikan tinjauan terhadap pengetahuan guru yang berbeda dengan gambaran yang diberikan pada abad sebelumnya. Sekarang, pengetahuan guru 
direpresentasikan sebagai kesetimbangan dinamis antara beberapa domain pengetahuan (teknologi, pedagogi, dan konten) dan keterampilan yang diperlukan seorang guru untuk mengajarkan konten tertentu pada tingkatan kelas tertentu.

Pengetahuan merupakan banyaknya informasi yang diperlukan untuk mencapai fungsi dan tujuan; kapasitas untuk menyusun informasi berdasarkan data dan mengubahnya menjadi informasi yang berguna dan bermakna; kapasitas dimana seseorang berpikir kreatif, menafsirkan dan bertindak; dan sebuah sikap yang membuat orang mau berpikir (uit Beijerse, 2000). Oleh karena itu, model TPACK adalah suatu pengetahuan yang terintegrasi dan bentuk pemikiran strategis: untuk mengetahui kapan, di mana, dan bagaimana menggunakan domain pengetahuan dan strategi tertentu ketika membimbing siswa belajar dengan menggunakan teknologi informasi dan komunikasi yang tepat (Shavelson, Ruiz-Primo, Li, \& Ayala, 2003). Pada dasarnya TPACK mendukung guru dalam mengorganisasi, mengimplementasi, mengkritisi hasil, serta mengabstraksi perencanaan materi pelajaran tertentu dan kebutuhan siswa ketika mengintegrasikan teknologi yang tepat.

\section{KONSEPTUALISASI TPACK SEBAGAI KERANGKA KERJA}

Berbicara mengenai pemahaman terhadap suatu konsep baru yang muncul berdasarkan pengembangan dari beberapa teori-teori yang telah dirumuskan sebelumnya tentunya akan seperti halnya melihat dua sisi pada uang logam. Sebab, pemahaman seseorang mengenai sebuah konsep yang baru bergantung pada pengetahuan serta wawasan yang dimiliki seseorang, khususnya pengetahuan serta wawasan yang berkaitan dengan konsep tersebut. Seperti halnya uang logam yang memiliki dua sisi, pemahaman seseorang terhadap suatu konsep yang dianggap baru pun memiliki dua perspektif, jika dilihat dari subjek yang memahami konsep tersebut. Disatu sisi pemahaman seorang pemula tentang sebuah konsep baru dan disisi lainnya pemahaman seorang pakar atau ahli tentang sebuah konsep baru yang sama. Tentunya pemahaman antara subjek satu dengan subjek yang lainnya akan menghasilkan interpretasi yang berbeda mengenai konsep yang baru tersebut. Seperti yang dipaparkan oleh Hatano dan Inagaki (1986) Pemahaman seorang pemula dibandingkan dengan seorang pakar dianggap menunjukkan hubungan yang serupa dengan pemahaman seorang anak dengan orang dewasa. Hal ini dikarenakan adanya perbedaan baik pengetahauan maupun pengalaman antara seorang pemula dengan seorang pakar.

Jika kita mengikuti analogi ini dan menganggap bahwa guru yang tidak berpengalaman atau dalam kasus sekarang yang tidak memiliki pengalaman atau pemahaman yang cukup dalam memanfaatkan teknologi dapat dianggap sebagai pemula (Berliner, 1992, 2001; Leinhardt \& Greeno, 1991), sangat mungkin untuk menerapkan temuan dan pertimbangan teoretis mengenai literatur perubahan konseptual yang dapat dijadikan pedoman oleh guru dalam mengembangkan pemahaman konseptual yang mereka miliki terkait dengan TPACK.

Mengingat literatur perubahan konseptual berdasarkan hal ini, menjadi jelas bahwa ada dua perspektif teoretis tentang bagaimana pemahaman konseptual yang baru yang terwakili secara kognitif. Pandangan pertama tentang pemahaman konseptual mengasumsikan para pemula untuk membangun sistem "Pengetahuan dalam potongan-potongan" yang terfragmentasi (menjadi beberapa bagian) dalam jumlah besar, yang walaupun tidak terstruktur secara sistematis namun saling terintegrasi (berkaitan) secara eksplanitif primitif dalam suatu konteks tertentu (Clark et al., 2011; diSessa et al., 2004). Pandangan lain mengasumsikan para pemula untuk membangun "Teori-Teori", yaitu teori kerangka kerja yang lebih koheren dan kompak yang dapat dikarakterisasi didalam beberapa penjelasan spesifik yang memiliki batasan-batasan. (Ioannides \& Vosniadou, 2002; Vosniadou \& Brewer, 1992).

Pemetaan kedua perspektif ini pada dasarnya membahas mengenai pertanyaan bagaimana mengkonseptualisasikan pengembangan TPACK akan memberikan dua asumsi berbeda, di satu sisi tentang bagaimana pengetahuan ini dapat diwakili dalam pikiran seorang pemula. Dan, di sisi lain, konseptualisasi TPACK sebagai kerangka kerja yang koheren (saling berhubungan) akan semakin terbukti sejalan dengan gagasan TPACK sebagai konstruksi meta-konseptual yang akan memberikan dasar untuk menguraikan TPACK sebagai teori ilmiah.

\section{KERANGKA KERJA TPACK SEBAGAI POTONGAN-POTONGAN PENGETAHUAN YANG TIDAK KOHEREN}

Dalam pendekatan mengenai "potongan-potongan di dalam pengetahuan" pemahaman konseptual terhadap suatu pengetahuan dianggap terdiri dari sejumlah besar "elemen intuitif", sedangkan beberapa elemen ini mungkin memiliki cakupan yang lebih luas. (mencakup lebih dari satu konteks) dan yang lainnya merupakan lingkup yang lebih sempit (hanya mencakup satu konteks) (Clark et al., 2011; diSessa et al., 2004). Elemen yang dimaksudkan disini didefinisikan sebagai sebuah fenomena yang dapat menggambarkan "apa yang terjadi secara alami di dunia" sehingga dapat disimpulkan bahwa setiap elemen yang membanguan pemahaman seseorang terhadap suatu konsep pengetahuan ditentukan dengan sendirinya, oleh karenanya 
spesifikasi terhadap keseluruhan konsep hampir tidak mungkin dilakukan sebab tidak memiliki batas yang pasti antar elemen yang satu dengan yang lainnya (elemen diperkirakan tumpang tindih antara konteks satu dengan yang lain).

Meskipun mengikuti lintasan perkembangan yang independen, subkelompok elemen dapat diberikan dalam situasi yang sama, hal itu menunjukkan koherensi lokal; Artinya, perspektif potongan-potongan di dalam pengetahuan tidak mengasumsikan interaksi acak murni antar elemen. Ketidakkonsistenan fenomena, bagaimanapun, hanya dapat dijelaskan pada tingkat resolusi yang samar-samar bahwa sesuatu yang mempengaruhi fenomena yang dimaksud harus bertindak secara berbeda (diSessa et al., 2004, hal 857). Belajar mengikuti pendekatan ini kemudian didefinisikan sebagai proses reorganisasi elemen dan keterkaitannya, yang dapat menghasilkan pemahaman secara menyeluruh (Clark et al., 2011). Jadi mengatur ulang unsur-unsur (primitif fenomenologis) akan menghasilkan beberapa hubungan antara konteks dan memprioritaskan unsur-unsur dengan kepentingan. Namun, bahkan jika ada unsur dengan atribut umum, jumlah mereka yang besar dan jalur perkembangan independen merupakan "suatu kesulitan intrinsik untuk mengembangkan pandangan terpadu [...]" (diSessa et al., 2004, hal 857). Sebagai konsekuensi dari hal ini, tidak ada kesadaran meta-konseptual dari teori seseorang yang dapat dicapai.

Bagi TPACK, seperti yang disebutkan di atas, tugas yang harus dikuasai oleh seorang guru adalah transformasi penggunaan teknologi dalam pengajaran. Konseptualisasi TPACK sebagai pemahaman yang tidak koheren mengarah pada asumsi bahwa pengetahuan guru abstrak (pemahaman pribadi) yang diperoleh dari situasi sehari-hari dalam profesi mengajar. Ini kemudian menghasilkan sejumlah besar elemen spesifik konteks (fenomenologis) seperti: "Di kelas ini, menggunakan kerja tim di laboratorium komputer menyebabkan kekacauan". Pada kondisi tersebut bukan berarti metode kerja tim tidak dapat dilakukan di laboratorium, Kondisi seperti itu mungkin saja terjadi karena adanya beberapa elemen yang akan mengarah pada penjelasan yang koheren secara lokal untuk konteks yang terkait seperti adanya hambatan baik dari segi kondisi siswa maupun alat (teknologi) yang digunakan, seperti: "Di sore hari, saat siswa lelah, kerja sama tim di laboratorium komputer menyebabkan kekacauan", kondisi tersebut menandakan terjadinya diferensiasi (pengelompokkan perbedaan) antara komponen di dalam domain. Sehingga, akan ada abstraksi yang terhubung secara longgar untuk sub-domain dasar, yaitu; teknologi, pedagogi, dan konten, dan juga pada tingkat kedua: strategi konten paedagogi (PCK), dampak teknologi pembelajaran yang berbeda (TPK) dan representasi teknologi spesifik konten (TCK). Akhirnya, TPACK diasumsikan juga terdiri dari sub-sampel elemen-elemen ini yang masing-masing menerapkan pada konteks, topik, teknologi, atau strategi pengajaran tertentu. Ini bisa sangat koheren, seperti: "Menggunakan kalkulator grafik dalam kerja sama tim bermanfaat untuk sejumlah topik matematika."

Dengan demikian, TPACK sebagai kerangka kerja yang dikonseptualisasikan dengan cara ini kurang bermanfaat untuk penalaran tentang perubahan kendala seperti kelas baru atau perangkat keras dan lunak yang muncul. Akhirnya, tidak mungkin pemahaman keseluruhan tentang tingkat meta-konseptual berkembang secara sistematis, yaitu apa yang dipahami oleh seorang guru tentang faktor-faktor yang terlibat dalam pengajaran dengan teknologi dan bagaimana mereka berinteraksi. Dengan mengikuti pendekatan ini, pengembangan TPACK kemudian berarti mengumpulkan elemen-elemen penjelasan yang lebih luas tentang bagaimana menggunakan teknologi dalam pengajaran yang dapat dihubungkan oleh atribut umum seperti konten serupa atau tujuan pembelajaran. Lebih konkret lagi, guru akan mengembangkan kumpulan contoh rencana pelajaran yang lebih besar yang dapat disempurnakan secara individual dari waktu ke waktu; Namun, dia tidak akan bisa mendefinisikan kerangka koheren yang mendasari pengajarannya dengan teknologi atau pengambilan keputusan masing-masing.

\section{KERANGKA KERJA TPACK SEBAGAI TEORI TEORI YANG KOHEREN}

Pemahaman konseptual sebagai Teori Teori oleh Vosniadou dan rekan-rekannya (mis., Vosniadou \& Brewer, 1992) mengasumsikan bahwa pendahuluan awal ontologis dan epistemologis pendidik disusun ke dalam teori kerangka kerja umum. Teori kerangka kerja itu bersifat kausal, penjelasan mengenai kerangka kerja yang mengatur fenomena fisik (Clark et al., 2011). Dibatasi oleh teori kerangka kerja ini, teori-teori spesifik (misalnya model mental) dan kepercayaan dibangun berdasarkan pengamatan sehari-hari dan informasi yang ditransmisikan secara budaya (kepercayaan) untuk menjelaskan, menafsirkan, atau memprediksi fenomena spesifik (Vosniadou, 1994). Belajar mengikuti konseptualisasi ini dianggap sebagai sebuah perkembangan dari model mental ke model mental melalui integrasi (penggabungan) antara informasi baru dan pembentukan model interim (Clark et al., 2011) oleh proses pengayaan atau revisi (Vosniadou, 1994). Sedangkan revisi bervariasi antara restrukturisasi yang lemah, mengacu pada peningkatan diferensiasi dan integrasi hierarki struktur yang ada, dan restrukturisasi radikal, mengacu pada munculnya struktur teoretis baru dari beberapa yang sudah ada sebelumnya (Vosniadou \& Brewer, 1992), perubahan seperti ini dianggap sulit untuk dicapai. Salah satu alasannya adalah bahwa perubahan prasangka ontologis dan epistemologis pasti 
memiliki implikasi serius pada semua struktur pengetahuan yang didasarkan pada mereka (Vosniadou, 1994). Untuk lebih mengembangkan teori yang masih awam seperti itu ke dalam pemahaman ilmiah, seseorang perlu memperoleh kesadaran meta-konseptual tentang teori kerangka kerja, yang menyinggung bentuk representasi kognitif yang berbeda (Ioannides \& Vosniadou, 2002).

Gagasan tentang model mental dalam pendekatan ini sesuai dengan yang dijelaskan di atas (Brewer, 1987; Clark et al., 2011; Vosniadou \& Brewer, 1992, 1994). Mereka dipahami sebagai representasi analog dari "keadaan darurat" yang memiliki struktur dinamis dan diciptakan di tempat untuk tujuan memecahkan masalah. Penciptaan model mental dianggap didasarkan dan dibatasi oleh struktur konseptual yang mendasarinya (teori kerangka kerja di atas) yang bertindak sebagai prasyarat yang sering didasarkan pada pengalaman sehari-hari. Dengan demikian, model mental awal terbentuk berdasarkan seperangkat praduga semacam itu. Informasi baru berasimilasi ke dalam model sintetis saat mencoba mempertahankan praduga sebanyak mungkin. Belajar dalam arti perubahan konseptual pada akhirnya berarti sebuah reinterpretasi dari praduga yang mendasarinya. Kesimpulannya, perdebatan tentang koherensi struktur pengetahuan tentang pemahaman naif (awam) tentang konsep ilmiah ini menambahkan perspektif teoretis yang berharga untuk dipertimbangkan berkaitan dengan bagaimana konsep konseptualisasi TPACK yang berbeda dapat menginformasikan penelitian mengenai perkembangannya.

Bagi TPACK, tugas yang harus dikuasai adalah transformasi penggunaan teknologi dalam pengajaran. Dengan cara ini, teori kerangka kerja dasar dapat mencakup pengandaian ontologis dan epistemologis seperti "Ada perangkat lunak pendidikan dan ada perangkat lunak untuk penggunaan pribadi" (ontologis), "Penggunaan teknologi yang muncul tidak berbeda dengan menggunakan jenis materi pengajaran" (ontologis), "Beberapa teknologi tidak dibuat untuk pembelajaran tidak perlu dijelaskan" (epistemologis), atau "Mengapa siswa belajar lebih baik dengan representasi tertentu perlu dijelaskan" (epistemologis). Konteks budaya guru, di mana informasi untuk membangun teori spesifik yang berkaitan dengan penggunaan teknologi diterima, dan dibentuk oleh epistemologi domain pada subjek (Buehl, Alexander, \& Murphy, 2002; Hofer, 2006b) dan profesi pengajaran itu sendiri. Dapat diasumsikan bahwa guru pra-jabatan pada umumnya adalah guru yang berpengalaman dengan tingkat integrasi teknologi rendah, meski tidak dapat memberikan alasan pedagogis untuk tingkat rendah ini, namun memiliki konsepsi naif mengenai apa yang dibatasi oleh TPACK. Sejalan dengan ini, mereka tidak akan memiliki kesadaran meta-konseptual tentang pengetahuan sub-domain yang dibahas sebelumnya yang perlu mereka atur agar memberi nilai tambah bagi skenario pembelajaran (rencana pembelajaran) dengan menggunakan teknologi baru. Mengikuti perspektif teori yang koheren, pengembangan TPACK berarti bahwa dengan membangun model mental awal berdasarkan prasyarat kerangka kerja dan kemudian terus mengintegrasikan informasi baru ke dalam model sementara, dari waktu ke waktu kerangka praduga akan berubah. Yang lebih penting lagi, para guru akan mengembangkan meta-kognitif tentang teori-teori lokal praduga mereka (misalnya rencana pembelajaran dan keputusan kelas) yang didasarkan pada bagaimana mereka menyusunnya. Perspektif ini juga menunjukkan bahwa guru "mengajar" tentang pemanfaatan teknologi baru secara inovatif memang sulit karena guru sebagai pendidik harus mencoba untuk mengubah praduga dasar. Mengubah ini tidak akan mudah dilakukan, tapi kemungkinan besar berhubungan dengan emosi yang tidak menyenangkan, karena ini mendekonstruksi cara telah dipercayai sebelumnya dalam memahami lingkungan pengajaran.

Contoh sejajar dengan yang ada di Bagian sebelumnya dapat berupa sebagai berikut: Seorang guru yang bertindak berdasarkan praduga "Ada perangkat lunak pendidikan dan ada perangkat lunak untuk penggunaan pribadi", telah belajar di kursus metode universitas bahwa video untuk sejarah pengajaran digunakan untuk mengilustrasikan konsep yang familiar bagi siswa, misalnya sebuah film dokumenter yang memberi gambaran umum tentang kurun waktu tertentu dalam sejarah. Kemudian dia belajar tentang teknologi video yang muncul yang memungkinkan seperti; pengguna memotong urutan, memesan kembali, menambahkan komentar subskrip, dan menyertakan fungsi berbagi untuk kolaborasi online. Dalam kursus pengembangan profesional, dia membuat rencana pelajaran untuk alat ini untuk penggunaan video tertentu dalam sejarah, seperti tujuan propaganda. Tugas siswa adalah membuat pesan baru dari materi video bersejarah yang disediakan untuk mendukung refleksi kritis mereka terhadap pesan media massa. Setelah membuat beberapa pengalaman seperti itu, pengembangan TPACK harus dilakukan dalam bentuk perubahan praduga sebelumnya. Alih-alih secara ketat memisahkan teknologi untuk penggunaan pendidikan dan pribadi, sekarang dia mungkin berasumsi: "Berdasarkan teknologi apa yang bisa dilakukan untuk siswa, guru dapat mengganti banyak teknologi yang berbeda untuk pendidikan". 


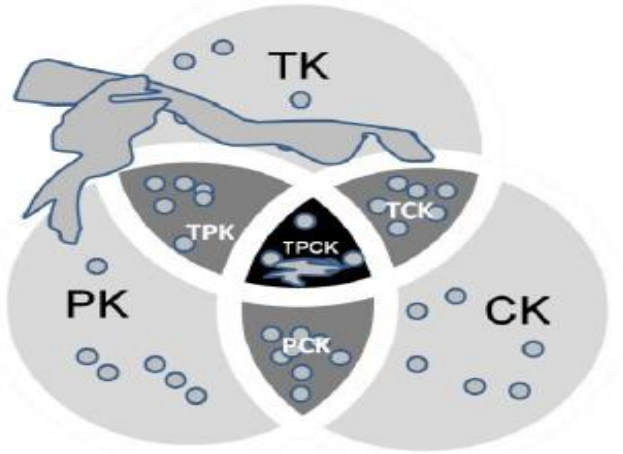

Gambar 3. TPACK sebagai sistem unsur penjelas lokal yang tidak koheren (Knowledge in Pieces). Teori kerangka kerja ilmiah TPACK "tertutup" oleh banyak elemen independen. Batas elemen tunggal mungkin tidak jelas, tumpang tindih, dan berbeda dalam lebar ruang lingkup.

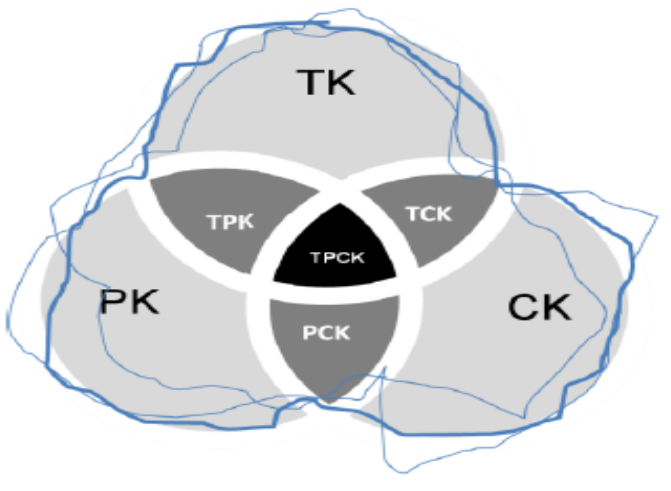

Gambar 4. TPACK sebagai teori intuitif yang koheren (Teori Teori). Batas konseptual diperkirakan sesuai dengan teori kerangka ilmiah TPACK, sementara batas-batasnya tidak jelas dan dapat berubah.

Singkatnya, pendapat dua tokoh dari diSessa dkk. (2004) diadaptasi untuk menggambarkan perbedaan antara perspektif Potongan-Potongan di dalam Pengetahuan dan Teori Teori karena dipetakan pada kerangka kerja TPACK (lihat Gambar 3 dan transformasi Gambar 4). Gambar 3 menggambarkan TPACK didefinisikan sebagai sistem elemen penjelas tunggal yang sebagian besar tidak koheren yang diabstraksikan dari pengalaman sehari-hari (pengajaran). Ini menggambarkan bagaimana seorang guru pemula yang belum mengembangkan TPACK mungkin mewakili pemahamannya sendiri tentang pengetahuan profesional tentang domain pengajaran dengan teknologi. Beberapa di antaranya mencakup konteks yang lebih luas dan melampaui batasan sub-domain, misalnya ke domain pribadi atau profesi lain. TPACK sendiri dalam ilustrasi ini adalah sub-sampel dari elemen-elemen, dimana aspek dari semua sub-domain dipertimbangkan. Ini tidak akan memberi nilai tambah TPACK sebagai tambahan sehubungan dengan bentuk representasinya. Konteksnya termasuk dalam kejadian tunggal yang elemen-elemennya didasarkan pada koherensi lokal untuk konteks dengan atribut serupa. Gambar 4 menggambarkan TPACK sebagai teori intuitif yang koheren oleh seorang guru. Ini menggambarkan bagaimana seorang guru yang telah mengembangkan TPACK perlu mewakili dirinya sendiri atau pemahamannya tentang pengetahuan profesional tentang ranah pengajaran dengan menggunakan teknologi. Mengikuti perspektif ini, memiliki pemahaman TPACK berarti mengembangkan sebuah konseptualisasi yang secara kasar mencakup sub-domain yang sama, keterkaitannya, dan peran konteks seperti yang diusulkan oleh kerangka kerja TPACK. Relevansi konteks di sini tersirat sejauh mana praduga teori kerangka kerja mendefinisikan konteks sebagai faktor yang relevan.

\section{PENUTUP : Peluang Penelitian}

Dari kajian literatur yang dilakukan penulis mengingat di Indonesia belum begitu banyak dilakukan penelitian terkait dengan TPACK, maka pertanyaan-pertanyaan berikut layak dijawab melalui penelitian-penelitian kepada guru. Pengetahuan apakah yang dibutuhkan oleh guru untuk mengajar saat ini dan masa mendatang dimana teknologi membawa dampak yang sangat berarti dalam berbagai cara kerja, dan interaksi manusia? Mengingat kondisi saat ini, guru masa kini dan masa yang akan datang harus siap untuk berpikir ulang, belajar, dan belajar kembali, mengubah, merevisi dan beradaptasi saat melakukan perencanaan, implementasi, dan menilai pembelajaran dengan teknologi baru ini. Pertanyaan utama bagi program persiapan guru adalah: pengalaman apakah dan bagaimanakah seharusnya pengalaman tersebut diatur agar calon guru dapat mengembangkan pengetahuan yang sesuai dengan kerangka TPACK dalam upaya untuk membentuk karakter atau kepribadian siswa?

Penelitian diperlukan untuk memperjelas TPACK sebagai suatu kerangka kerja tentang pengetahuan guru. Apakah TPACK merupakan irisan dari beberapa domain yang mewakili semua pengetahuan yang dibutuhkan guru untuk mengajar dengan menggunakan teknologi? Cara apakah yang paling tepat untuk mengukur TPACK sebagai konsep pengetahuan? Penelitian diperlukan untuk menilai keyakinan dan pengalaman guru yang mengarah pada bagaimana mereka berpikir tentang konten dan bagaimana konten tersebut dipelajari dalam hubungannya dengan penggunaan teknologi yang tepat untuk melibatkan siswa dalam pembelajaran. Penelitian diperlukan untuk mendeskripsikan lintasan pembelajaran guru dalam mengembangkan pengetahuan dan keterampilan untuk menggabungkan teknologi baru dan yang sedang 
Prosiding Seminar Nasional Pendidik dan Pengembang Pendidikan Indonesia dengan Tema "Membangun Generasi Berkarakter Melalui Pembelajaran Inovatif”. Aula Handayani IKIP Mataram 14 Oktober 2017. ISSN 2598-1978

berkembang sebagai alat belajar dan mengajar di berbagai topik sehingga dapat memperkuat dan meningkatkan pengetahuan siswa.

Dari beberapa observasi yang dilakuan oleh penulis, tampak bahwa guru-guru matematika masih banyak yang memiliki level TPACK yang rendah. Hal ini memberikan peluang penelitian sendiri terkait dengan bagaimana strategi untuk meningkatkan level TPACK guru-guru matematika. Pengembangan metode sampai pada model pelatihan untuk meningkatkan TPACK menjadi bahan penelitian yang menarik

\section{DAFTAR RUJUKAN}

American Association for the Advancement of Science. (1989). Project 2061: Science for all Americans. Washington, DC: AAAS.

Angeli, C., \& Valanides, N. (2005). Preservice elementary teachers as information and communication technology designers: An instructional systems design model based on an expanded view of pedagogical content knowledge. Journal of Computer Assisted Learning, 21(4), 292-302.

Bearison, J. D., \& Dorval, B. (2002). Collaborative cognition. Westport, CT: Ablex.

Cavus, Nadire \& Huseyin Uzunboylu.(2009).Improving critical thinking skills in mobile learning, Procedia Social and Behavioral Sciences, 1(2009), 434-438

Despres, Charles \& Chauval, Daniele.(2000).Knowledge Horizons: The Present and The Promise of Knowledge Management”. Boston, Oxford, Auckland, Johannesberg, Melbourne, New Delhi:Butterworth Heinemann.

Doering, A., Veletsianos, G., Scharber, C., \& Miller, C. (2009). Using technological pedagogical content knowledge framework to design online environments and professional development. Journal of Educational Computing, 41(3), 319-346

Eggen, Paul., Kauchak, Don. (2007). Educational Psychology Windows on Classroom $7^{\text {th }}$ ed .New Jersey: Pearson Education, Inc.

Greeno, J. G., Collins, A., \& Resnick, L. B. (1996). Cognition and learning. In Berliner, D. C., \& Calfee, R. C. (Eds.), Handbook of educational psychology. New York, NY: Macmillan.

Guerrero, S. (2010). Technological pedagogical content knowledge in the mathematics classroom. Journal of Digital Learning in Teacher Education, 26(4), 132-139.

Harrington, R. A. (2008). The development of preservice teachers' technology specific pedagogy. Dissertation Abstracts International-A, 69(3).

Harris, J., Grandgenett, N., \& Hofer, M. (2010). Testing a TPACK-based technology integration assessment rubric. In D. Gibson \& B. Dodge (Eds.), Proceedings of Society for Information Technology \& Teacher Education International Conference 2010 (pp. 3833-3840). Chesapeake, VA: AACE

Koh, J. L., \& Divaharan, S. (2011). Developing pre-service teachers' technology integration expertise through the TPACKdeveloping instructional model. Journal of Educational Computing Research, 44(1), 35-58.

Koehler, M. J., \& Mishra, P. (2008). Introducing TPCK. In AACTE Committee on Innovation and Technology (Eds.), Handbook of technological pedagogical content knowledge (TPCK) for educators, New York, NY: Routledge.

Koehler, Matthew J., and Punya Mishra. (2009). What is Technological Pedagogical Content Knowledge?. Contemporary issues in Technology and Teacher education, (1), 60-70

Listiawan, T., \& Baskoro, W. W. (2015). Analisis Technological Content Knowledge (TCK) Calon Guru Matematika Dalam Menggunakan Perangkat Lunak Geometri Dinamis, Prosiding Seminar Nasional Matematika Dan Pendidikan Matematika UNY, 827-834

Mishra, P., \& Koehler, M. J. (2006). Technological pedagogical content knowledge: A framework for teacher knowledge.Teachers College Record, 108(6), 1017-1054.

Motiwalla, Luvai F. (2007). Mobile learning: A framework and evaluation, Computers \& Education, 49(2007), 581-596.

Niess, M. L. (2005). Preparing teachers to teach science and mathematics with technology: Developing a technology pedagogical content knowledge. Teaching and Teacher Education, 21(5), 509-523.

Niess, M. L. (2006). Guest editorial: Preparing teachers to teach mathematics with technology. Contemporary Issues in Technology and Teacher Education, 6, 1-9.

Niess, M. L., Ronau, R. N., Shafer, K. G., Driskell, S. O., Harper S. R., Johnston, C., Browning, C., Özgün-Koca, S. A., \& Kersaint, G. (2009). Mathematics teacher TPACK standards and development model. Contemporary Issues in Technology and Teacher Education, 9(1), 4-24.

Niess, M. L., Suharwoto, G., Lee, K., \& Sadri, P. (2006, April). Guiding inservice mathematics teachers in developing TPCK. Paper presented at the American Education Research Association Annual Conference, San Francisco, CA. 
Prosiding Seminar Nasional Pendidik dan Pengembang Pendidikan Indonesia dengan Tema "Membangun Generasi Berkarakter Melalui Pembelajaran Inovatif”. Aula Handayani IKIP Mataram 14 Oktober 2017. ISSN 2598-1978

Niess, M. L., Lee, J. K., \& Kajder, S. B. (2008). Guiding learning with technology. Hoboken, NJ:John Wiley \& Sons.

Parkay, F. W., \& Stanford, B. H. (2009). Becoming a teacher (8th ed.). Boston, MA: Allyn and Bacon

Santrock, J. W. (2006). Educational psychology. Boston, MA: McGraw Hill.

Schmidt, D. A., Baran, E., Thompson, A. D., Mishra, P., Koehler, M. J., \& Shin, T. S. (2009). Technological pedagogical content knowledge (TPACK): The development and validation of an assessment instrument for preservice teachers. Journal of Research on Technology in Education, 42(2), 123-149.

Shafer, K. G. (2008). Learning to teach with technology through an apprenticeship model. Contemporary Issues in Technology \& Teacher Education, 8(1), 27-44.

Sharples, Mike.(2000). The design of personal mobile technologies for lifelong learning, Computers \& Education,34(2000), 177-193.

Sharples dkk.(2003). Guidelines for learning in a mobile environment MOBIlearn/UoN,UoB,OU/D4.1/1.0.

Shavelson, R., Ruiz-Primo, A., Li, M., \& Ayala,C. (2003, August). Evaluating new approaches to assessing learning (CSE Report 604). Los Angeles, CA: University of California, National Center for Research on Evaluation.

Shulman, L. S. (1986). Those who understand: Knowledge growth in teaching. Educational Researcher, 15(2), 4-14.

Shulman, L. S. 1987. Knowledge and teaching: Foundation of the new reform. HarvardEducational Review. 57(1).

So, H., \& Kim, B. (2009). Learning about problem based learning: Student teachers integrating technology, pedagogy and content knowledge. Australasian Journal of Educational Technology, 25(1), 101-116.

Tee, M., \& Lee, S. (2011). From socialisation to internalisation: Cultivating technological pedagogical content knowledge through problem-based learning. Australasian Journal of Educational Technology, 27(1), 89-104.

Thompson, A., \& Mishra, P. (2007). Breaking news: TPCK becomes TPACK! Journal of Computing in Teacher Education, 24(2), 38-64.

uit Beijerse, R. P. (2000). Questions in knowledge management: Defining and conceptualizing a phenomenon. Journal of Knowledge Management,3, 94-109.

Shavelson, R., Ruiz-Primo, A., Li, M., \& Ayala, C. (2003). Evaluating new approaches to assessing learning (CSE Report 604). Los Angeles, CA: University of California, National Center for Research on Evaluation.

Wilson, S. M., Shulman, L. S., \& Richert, A. E. (1987). 150 different ways of knowing: Representations of knowledge in teaching. In Calderhead, J. (Ed.), Exploring teachers' thinking (pp. 104-124). London, UK: Cassell.

Woolfolk, A. (2008). Educational psychology: Active learning edition. Boston, MA: Pearson Allyn \& Bacon. 